\title{
Kenny Music Performance Anxiety Inventory (K- MPAI): Exploratory Factor Analysis of the Ukrainian version
}

\author{
Olena Ksondzyk
}

Institute of Social and Political Psychology of National Academy of Educational Science, Kyiv, Ukraine

\begin{abstract}
Introduction: Music performance anxiety (MPA) is one of the most common psychological problems among musicians, regardless of their age, gender or level of stage experience. Since empirical studies of this subject are just emerging in Ukraine, there is a lack of psychometrically valid instruments for measuring it. Many specific instruments are ovailable to evaluate MPA in English, but they have to be adapted for the Ukrainian population. One of such significant psychodiagnostic tools is the Kenny Music Performance Anxiety Inventory (K-MPAl) used for different cultural contexts.
\end{abstract}

Purpose: The aim of this research is to study the factor structure of the Ukrainian version of KMPAl.

Methodology: In order to assess the K-MPAl's linguistic and conceptual equivalence, the questionnaire was translated using blind back-translation method. Thereafter, the sample of 252 professional musicians (aged 19-66, $M=38, S D=11.24 ; 59 \%$ women and $41 \% \mathrm{men}$ ) completed the K-MPAI.

Results: An exploratory factor analysis with principal axis factoring and oblimin rotation method was performed based on the K-MPAl items. The optimal implementation of parallel analysis revealed three factors that explain $44.99 \%$ of variance; they are named "proximal performance concerns", "early relationship context", and "psychological vulnerability". The internal consistency of the Ukrainian version of K-MPAl presents excellent value with Cronbach's alpha of 0.871 and high temporal stability $(r=.84 ; p<0.001)$.

Discussion \& Conclusions: These findings demonstrate evidence of construct validity and reliability of the Ukrainian version of K-MPAl and partially support the theoretical model that became the basis for the development of the original measure. This questionnaire can be used as a valid tool to assess MPA in Ukrainian scientific research.

\section{Keywords}

anxiety, performance, musicians, adaptation, test validity, factor structure

Address for correspondence:

Olena Ksondzyk, Laboratory of social psychology of personality, Institute of Social and Political Psychology, NAES of Ukraine, e-mail: olenaksondzyk@gmail.com

This work is licensed under a Creative Commons Attribution-

NonCommercial 4.0 International License (CC BY-NC 4.0).

(c) (7) (8)

DOI: http://dol.org/10.32437/mhgcj.v4i2.87

Submitted for publication: 23 May 2020 Received: 23 May 2020 Accepted for publication: 30 September 2020 
Special Issue -

MHGC Proceeding 2020

\section{Introduction}

Music performance anxiety (MPA) is a particular state of stressful and persistent apprehension related to music performance in front of an audience (Kenny, 2011; Salmon, 1990; Spahn et al., 2016). The core of this anxiety is fear of professional failure, negative evaluation by audience, and possible consequences, though its optimal level is beneficial for the quality of performance. An excessive degree and repeated experiences of performance anxiety can cause increased tension, loss of adequate self-esteem and deterioration of self-efficacy.

MPA is manifested through affective, cognitive, somatic, and behavioural symptoms along a broad continuum of varying severity from adaptive responses to pathological forms (Kenny, 201 1; Spahn et al., 2016). Considering all diagnostic criteria, MPA is classified as a "performance only" subtype of social anxiety disorder in DSM-V (APA, 2013).

Despite the highly developed music education in Ukraine, the empirical studies of music performance anxiety have not been conducted due to several reasons. First, professional musicians tend to stigmatize and silence this problem, avoiding psychological help. The second significant obstacle to obtaining reliable data is the lack of valid special psychodiagnostic tools for its assessment. In this context, the Kenny Music Performance Anxiety Inventory (K-MPAl) deserves special attention. Based on Barlow's emotion theory of the etiology of anxiety and its disorders (Barlow, 2002), this questionnaire integrates cognitive, emotional, and physiological aspects of MPA taking into account its etiological complexity. The K-MPAI demonstrates excellent psychometric properties (Barbar et al., 2015; Kenny, 2004; Zarza-Alzugaray et al., 2016).

\section{Purpose}

The purpose of this research is to study the internal factor structure of K-MPAl based on a sample of the Ukrainian population.

\section{Methodology}

\section{Participants}

The sample consists of 252 adult musicians from various regions of Ukraine (Lviv, IvanoFrankivsk, Kyiv, Ternopil, Kharkiv), who work in state institutions of music education (music academies) and philharmonic societies (aged
19-66, $\mathrm{M}=38, \mathrm{SD}=11.24 ; 59 \%$ women and $41 \%$ men). Ethical approval was obtained from the Laboratory of the Social Psychology of Personality at the Institute of Political and Social Psychology in Kyiv. Thereafter, data have been collected during a concert season that represents a typical schedule of rehearsals and performances. The musicians were guaranteed voluntary participation and anonymity. The criteria for inclusion in the study were age over 18 years old and frequent participation in public musical performances, while the exclusion criterion was the incorrect filling out of the form. Characteristics related to the participants' musical genre and instrument category representation are presented in Table 1.

Table 1: Sample Characteristics ( $\mathrm{N}=\mathbf{2 5 2}$ )

\begin{tabular}{|c|c|c|}
\hline $\begin{array}{c}\text { Main music } \\
\text { genre }\end{array}$ & N & Percentage (\%) \\
\hline Classical & 185 & $73 \%$ \\
\hline Pop & 35 & $14 \%$ \\
\hline Folk & 19 & $8 \%$ \\
\hline Jazz & 7 & $3 \%$ \\
\hline Rock & 6 & $2 \%$ \\
\hline $\begin{array}{c}\text { Instrument } \\
\text { category }\end{array}$ & $\mathbf{N}$ & Percentage (\%) \\
\hline Piano & 106 & $42 \%$ \\
\hline Voice & 37 & $15 \%$ \\
\hline Conducting & 33 & $13 \%$ \\
\hline String & 31 & $12 \%$ \\
\hline Wind & 26 & $10 \%$ \\
\hline Bandura & 19 & $8 \%$ \\
\hline
\end{tabular}

\section{Adaptation procedure}

Initially, the permission to adapt the K-MPAI for the Ukrainian population was obtained from the author Dianna Theodore Kenny, Professor at the University of Sydney, Australia. Then the questionnaire was translated according to the procedures provided by the requirements for cross-cultural adaptation of the methods outlined in international standards (Bartram, D., \& Hambleton, R. K., 2016). The following steps were performed:

- Ukrainian version of the original K-MPAI was prepared.

- Reverse translation into the original language was made by another bilingual translator. 
Special Issue -

MHGC Proceeding 2020

- Third specialized translation back into Ukrainian was made.

- $\quad$ The best version was chosen (taking into consideration the following criteria: clarity (intelligibility), conceptual, content, semantic and cultural equivalence). Following the translation procedure, a group of music students ( $N=30$ ) completed the questionnaire and stated that all statements were clear.

- Translations were compared, and the most reliable translation was selected.

A professional translator, native Ukrainian and English speakers, as well as several psychologists with clinical experience and previous expertise in adapting measures were involved in the translation of the questionnaire. The final version of the inventory was sent to the Author for approval and then recommended for further adaptation procedures.

\section{Instruments}

Kenny Music Performance Anxiety Inventory (KMPAl) (Kenny et al., 2004) is the scale that includes 26 items implying cognitive, behavioural, and somatic characteristics of anxiety in the context of music performance. It takes into account Barlow's theoretical components (Barlow, 2002) such as evocation of anxious propositions (e.g., uncontrollability, unpredictability, negative affect, situational cues); attentional shift (e.g., task or self-evaluative focus, fear of negative evaluation); physiological arousal; and memory bias. There have been two published versions of the K-MPAl for adult musicians: the 26-item original version (Kenny et al., 2004) and the modified 40-item questionnaire (Kenny, 2009). In the current study, we choose the initial version, which is essential for screening.

\section{Data analysis}

- The sample's clinical and socialdemographic data are characterized using descriptive statistics.

- The exploratory factorial analysis is carried out to verify the structural validity of the $\mathrm{K}$ MPAl.

- Assessment of the internal consistency of statements is identified based on Cronbach's alpha;

- $\quad$ Temporal stability is measured using the testretest procedure; 20

\section{Results}

\section{Descriptive statistics}

Descriptive statistics for K-MPAl are presented in Table 2.

Table 2. Mean and standard deviation of the K-MPAI

$$
(N=252) \text {. }
$$

\begin{tabular}{|c|c|c|c|c|c|}
\hline $\begin{array}{c}\text { Inventor } \\
\mathrm{y}\end{array}$ & Min & Max & $\mathrm{M}(\mathrm{SD})$ & $\begin{array}{c}\text { Male M } \\
(\mathrm{SD})\end{array}$ & $\begin{array}{c}\text { Female } \\
\mathrm{M}(\mathrm{SD})\end{array}$ \\
\hline K-MPAl & 18 & 124 & $66(24)$ & $63(24)$ & $67(24)$ \\
\hline
\end{tabular}

There is no significant gender difference, but women are scored slightly higher. The mean total score on the K-MPAl is higher than the mean score reported by Kenny (2004; $N=32, M=54.21$, $\mathrm{SD}=34.21$, Minimum $=3$, Maximum $=111$ ), but lower than the mean score reported by ZarzaAlzugaray et al. (2016; $\mathrm{N}=275, \mathrm{M}=88.87, \mathrm{SD}=$ 21.24).

\section{EFA}

The factor structure of the Ukrainian version of the K-MPAl was assessed using a principal axis factoring with oblimin rotation, which is preferable when a correlation between factors exist (Tabachnick and Fidell, 2013). An appropriate Kaiser-Meyer-Olkin (KMO) measure of sampling adequacy and a statistically significant Bartlett's test of sphericity were obtained, thus justifying the use of the factor model (Table 3)

Table 3. KMO and Bartlett's test.

\begin{tabular}{|c|c|c|}
\hline \multicolumn{2}{|c|}{$\begin{array}{c}\text { Kaiser-Meyer-Olkin Measure of } \\
\text { Sampling Adequacy }\end{array}$} & .892 \\
\hline \multirow{2}{*}{$\begin{array}{c}\text { Bartlett's Test of } \\
\text { Sphericity }\end{array}$} & $\begin{array}{c}\text { Approx. Chi- } \\
\text { Square }\end{array}$ & 2515.272 \\
\cline { 2 - 3 } & df & 325 \\
\cline { 2 - 3 } & Sig. & $<0.001$ \\
\hline
\end{tabular}

We have identified seven factors with eigenvalues greater than Kaiser's criterion of 1. They explain $62.79 \%$ of variance. Factor 1 contributes to more than $30.67 \%$ of the variance, whereas the other factors are less than 10\% each. Since Kaiser's method tend to overestimate the number of components (Tabachnick \& Fidell, 2013), we apply a parallel analysis with the syntax provided by O'Connor (2000). We have obtained a solution of three factors, which explain $44.99 \%$ of variance. We have chosen a cutoff .416, because this best interprets the factor structure. The items which do not meet the loading criterion are deleted $(2,3,8,26)$.

The first factor is named "Proximal performance concerns" (1 1 items: $7,10,12,13$, 
Special Issue -

MHGC Proceeding 2020

$14,15,17,18,20,22,25)$; the second factor is named "Early relationship context" (3 items: 9, 19, $24)$, and the third factor is named "Psychological vulnerability" (8 items: 1, 4, 5, 6, 11, 16, 21, 23). The factor loadings on these three factors are presented in Table 4

Table 4. Factor structure of the K-MPAI for the Ukrainian sample

\begin{tabular}{|c|c|c|c|}
\hline \multirow[b]{2}{*}{ Item } & \multicolumn{3}{|c|}{ Factor } \\
\hline & 1 & 2 & 3 \\
\hline $\begin{array}{l}12 \text { During a performance, I find } \\
\text { myself thinking about whether I'll } \\
\text { get through it }\end{array}$ & .814 & & \\
\hline $\begin{array}{l}13 \text { Thinking about the evaluation, } \\
\text { I may get interfered with my } \\
\text { performance }\end{array}$ & .773 & & \\
\hline $\begin{array}{l}10 \text { I never know before a concert } \\
\text { whether I will perform well }\end{array}$ & .761 & & \\
\hline $\begin{array}{l}22 \text { I often prepare for a concert } \\
\text { with a sense of dread and } \\
\text { impending disaster }\end{array}$ & .756 & & \\
\hline $\begin{array}{l}18 \text { I worry that one bad } \\
\text { performance may ruin my career }\end{array}$ & .675 & & \\
\hline $\begin{array}{l}7 \text { Even if I work hard in } \\
\text { preparation for a performance, I } \\
\text { am likely to make mistakes }\end{array}$ & .640 & & \\
\hline $\begin{array}{l}14 \text { Even in the most stressful } \\
\text { performance situations, I am } \\
\text { confident that I will perform well }\end{array}$ & .633 & & \\
\hline $\begin{array}{l}25 \text { I worry so much before a } \\
\text { performance, I cannot sleep }\end{array}$ & .628 & & \\
\hline $\begin{array}{l}\text { 15 I am often concerned about a } \\
\text { negative reaction from the } \\
\text { audience }\end{array}$ & .627 & & \\
\hline $\begin{array}{lll}17 \text { From early in my } & \text { music } \\
\text { studies, I remember } & \text { being } \\
\text { anxious about performing } & \end{array}$ & .524 & & \\
\hline $\begin{array}{l}20 \text { I give up worthwhile } \\
\text { performance opportunities due to } \\
\text { anxiety }\end{array}$ & .497 & & \\
\hline $\begin{array}{l}19 \text { My parents always listened to } \\
\text { me }\end{array}$ & & .780 & \\
\hline $\begin{array}{l}9 \text { My parents were mostly } \\
\text { responsive to my needs }\end{array}$ & & .620 & \\
\hline $\begin{array}{l}24 \text { My parents encouraged me to } \\
\text { try new things }\end{array}$ & & .498 & \\
\hline $\begin{array}{l}5 \text { Excessive worrying is a } \\
\text { characteristic of my family }\end{array}$ & & & .697 \\
\hline $\begin{array}{l}16 \text { Sometimes I feel anxious for } \\
\text { no particular reason }\end{array}$ & & & .695 \\
\hline $\begin{array}{l}1 \text { Sometimes I feel depressed } \\
\text { without knowing why }\end{array}$ & & & .678 \\
\hline
\end{tabular}

\begin{tabular}{|c|c|}
\hline $\begin{array}{l}11 \text { I often feel that I am not worth } \\
\text { much as a person }\end{array}$ & .617 \\
\hline $\begin{array}{l}6 \text { I often feel that life has not } \\
\text { much to offer me }\end{array}$ & .592 \\
\hline $\begin{array}{l}23 \text { I often feel that I have nothing } \\
\text { to look forward to }\end{array}$ & .569 \\
\hline $\begin{array}{l}4 \text { I often find it difficult to work up } \\
\text { the energy to do things }\end{array}$ & .528 \\
\hline 21 As a child, I often felt sad & .416 \\
\hline
\end{tabular}

\section{Reliability}

The internal consistency of the Ukrainian version of K-MPAl presents excellent value with a Cronbach's alpha of 0.871 . The $\alpha$-Cronbach coefficients for factors 1,2 and 3 are higher for the Ukrainian factor structure than for the original model (Kenny et al., 2004), Spanish (ZarzaAlzugaray et al., 2016), and Brazilian Portuguese (Barbar et al, 2014; Barbar et al, 2015) (Table 5).

Table 5. $\alpha$-Cronbach coefficients for the Ukrainian version of K-MPAl, compared to the original and other cultural adaptations

\begin{tabular}{|c|c|c|c|c|}
\hline Factor & $\begin{array}{c}\text { Ukrainia } \\
n, \\
N= \\
252 \\
\end{array}$ & $\begin{array}{c}\text { Origin } \\
\text { al, } \\
N= \\
32 \\
\end{array}$ & $\begin{array}{c}\text { Spanis } \\
\text { h, } \\
N= \\
490\end{array}$ & $\begin{array}{c}\text { Brazilian } \\
\text { Portugues } \\
e_{1} \\
\mathrm{~N}=230 \\
\end{array}$ \\
\hline $\begin{array}{l}\text { "Proximal } \\
\text { performanc } \\
\text { e concerns" } \\
\text { (11 items) }\end{array}$ & .900 & - & .868 & .82 \\
\hline $\begin{array}{l}\text { "Early } \\
\text { relationship } \\
\text { context" (3 } \\
\text { items) }\end{array}$ & .663 & - & .568 & .57 \\
\hline $\begin{array}{l}\text { "Psychologi } \\
\text { cal } \\
\text { vulnerability" } \\
\text { ( } 8 \text { items) }\end{array}$ & .825 & - & .786 & .77 \\
\hline Total & .871 & .944 & .866 & .82 \\
\hline
\end{tabular}

Temporal stability was measured using the testretest procedure. The results obtained for 30 participants showed a high temporal stability of the K-MPAl results $(r=.84 ; \mathrm{p}<0,001)$, which suggests good reliability of the K-MPAl as a scale

\section{Discussion \& Conclusion}

This study aims to adapt to the Ukrainian version of K-MPAl. This measure is chosen among other anxiety evaluation tools since it is designed within D. H. Barlow's theoretical model of emotional disorders, and is adapted by Dianna Kenny for assessing the development and maintenance of MPA (Barlow, 2000; Kenny, 2011).

Adhering to this aim, we provided a doubletranslation of the 26-item English-language 
Special Issue -

MHGC Proceeding 2020

parent form and conducted a pilot-study to confirm the face validity of the Ukrainian version of the scale, which did not undergo any modifications, compared to the initial version.

Following the EFA procedure using principal axis factoring with oblimin rotation, we obtained three factors related to certain aspects of Barlow's theoretical model. The first factor "Proximal performance concerns" (11 items: 7, 10,12, 13, $14,15,17,18,20,22,25$, Cronbach's $\alpha=.900$ ) reveals specific psychological vulnerability of musicians; the second factor "Early relationship context" (3 items: 9, 19, 24, Cronbach's $\alpha=.663$ ) demonstrates the features of early family context, and the third factor "Psychological vulnerability" (8 items: 1, 4, 5, 6, 11, 16, 21, 23, Cronbach's $\alpha=.825)$ identifies generalized psychological vulnerability. Some items related to the original K-MPAl, such as trust in others (2.8), controllability (3), and reliability of memory (26), demonstrated low factor loading and were not taken into consideration. By its content, the factor model is close to the Spanish version (ZarzaAlzugaray at al., 2016) and Brazilian Portuguese version (Barbar at al., 2015).

The Ukrainian version of K-MPAl presents a high internal consistency with Cronbach's alpha value of .871. High reliability of the K-MPAl as a measure is confirmed by the test-retest procedure that reveals high temporal stability of the K-MPAl results $(r=.84 ; p<0.001)$.

Certain limitations of the current study should be noted. First, the sample is composed of adult professional musicians, and most of them are representative of the classical music genre (73\%). However, it is important to investigate the manifestations of MPA in samples of other ages (university students in particular) and other musical genres (e.g., folk, jazz, rock, pop). Second in this study, only exploratory factor analysis was performed on the K-MPAl items, but some additional statistical procedures (e.g., CFA) can be carried out to test the resulting threedimensional model. Future studies could further investigate the convergent and divergent validity of the K-MPAl on the Ukrainian musicians.

The Ukrainian version of K-MPAl has acceptable psychometric properties. Therefore, the measure may be used by specialists as an assessment tool for screening MPA. Since this is the first study to investigate the factorial structure of the K-MPAl in the Ukrainian population, this paper may be useful for further research of MPA and evaluation of treatment efficacy.

\section{Acknowledgment}

I would like to express my gratitude to Professor Dianna Kenny for granting the authorization to use the K-MPAl in the current study. I also would like to thank all the musicians, students, and administrative staff of music academies for their participation in the study.

\section{Conflict of interest}

The author declares no potential conflicts of interest with respect to the research, authorship, and/or publication of this article.

\section{References}

American Psychiatric Association. (2013). Diagnostic and statistical manual of mental disorders (5th ed.). Washington, D C: Author.

Barbar A.E.M., Crippa JAS, Osório F.L. (2014) Performance anxiety in Brazilian musicians: Prevalence and association with psychopathology indicators. Journal of Affective Disorders, 152(154), 381-6. DOl: 10.1016/j.jad.2013.09.041

Barbar, A. E. M., Souza, J. A. D., \& Osório, F. D. L. (2015). Exploratory factor analysis of Kenny Music Performance Anxiety Inventory (K-MPAl) in a Brazilian musician sample. Archives of Clinical Psychiatry (São Paulo), 42(5), 113-1 16. DOI: 10.1590/0101-60830000000060

Barlow D. H. (2002). Anxiety and its disorders: The nature and treatment of anxiety and panic (2nd ed.). New York: The Guilford Press.

Bartram, D., \& Hambleton, R. K. (2016). The ITC guidelines: International standards and guidelines relating to tests and testing. In F. T. L. Leong, D. Bartram, F. M. Cheung, K. F. Geisinger, \& D. lliescu (Eds.), The ITC international handbook of testing and assessment (pp. 35-46). Oxford University Press.

Kenny, D. T. (2009). The factor structure of the Revised Kenny Music Performance Anxiety Inventory. In A. Williamon (Ed.), Proceedings of the International Symposium on Performance Science (pp. 37-41). Utrecht, The Netherlands: Association Europenne des Conservatoires.

Kenny, D.T. (2011). The Psychology of Music Performance Anxiety. Oxford: Oxford University Press.

Kenny, D. T., Davis, P. J., \& Oates, J. (2004). Music performance anxiety and occupational stress amongst opera chorus artists and their relationship with state and trait anxiety and perfectionism. Journal of Anxiety Disorders, 
Special Issue -

MHGC Proceeding 2020

18(6), 757-777. DOl: $10.1177 / 0305735612463950$

O'Connor, B. P. (2000). SPSS and SAS programs for determining the number of components using parallel analysis and Velicer's MAP test. Behavior Research Methods, Instruments, \& Computers, 32, 396-402. DOl: 10.3758/bf03200807

Salmon, P. (1990). A psychological perspective on music performance anxiety: A review of the literature. Medical Problems of Performing Artists, 5, 2-11.

Spahn, C., Walther, J., \& Nusseck, M. (2016). The effectiveness of a multimodal concept of audition training for music students in coping with music performance anxiety. Psychology of Music, 44 (4), 893-909. DOl: $10.1177 / 0305735615597484$

Tabachnick, B. G., \& Fidell, L. S. (2013). Using multivariate statistics. Upper Saddle River, $\mathrm{NJ}$ :Pearson Education.

Zarza-Alzugaray, F. J., Orejudo, S., Casanova, O., and Mazas, B. (2016). Kenny Music Performance Anxiety Inventory: Confirmatory factor analysis of the Spanish version. Psychol. Music, 44, 340-352. DOl: $10.1177 / 0305735614567932$ 